\title{
Quantification of the Relative Virulence of White Spot Syndrome Virus (WSSV) in the Penaeid Shrimps Litopenaeus vannamei (Boone, 1931) and Farfantepenaeus duorarum (Burkenroad, 1939) by Quantitative Real Time PCR
}

\section{Rey J. dela Calzada ${ }^{1}$, Jeffrey M. Lotz ${ }^{2}$}

${ }^{1}$ Department of Fisheries, Visayas State University-Tolosa, Tanghas, Tolosa, Leyte 6503 Philippines, ${ }^{2}$ Department of Coastal Sciences, The University of Southern Mississippi, Gulf Coast Research Laboratory, PO Box 7000, Ocean Springs, Mississippi 39566-7000, USA

\begin{abstract}
The relative virulence of the China isolate of white spot syndrome virus (WSSV-CN) in the penaeid shrimps Litopenaeus vannamei and Farfantepenaeus duorarum, was assessed by a comparison of $7-d$ median lethal dose $\left(\mathrm{LD}_{50}\right)$, survival curve, and mean lethal load after exposure by injection. Shrimps were injected intramuscularly with known WSSV dose. Median lethal dose of L. vannamei was lower than that of $F$. duorarum. Log $\mathrm{LD}_{50}$ in L.vannamei was 4.20 WSSV genome copies $\mu \mathrm{g}^{-1}$ total DNA. Log $\mathrm{LD}_{50}$ in F.duorarum was 5.32 WSSV genome copies $\mu \mathrm{g}$ ${ }^{1}$ total DNA. Median survival times of L. vannamei and F. duorarum injected with $10^{4}$ and $10^{5}$ WSSV genome copies were $54.17 \mathrm{~h}$ and $38.91 \mathrm{~h}$, respectively for $L$. vannamei whereas they were $119.58 \mathrm{~h}$ and $82.67 \mathrm{~h}$, respectively for $F$. duorarum. Mean log of the WSSV lethal load for L. vannamei was 9.34(SE \pm 9.09 ) copies $\mu \mathrm{g}^{-1}$ of total DNA and for F. duorarum was 11.80 (SE \pm 11.55 ). No significant difference was noted in lethal load for the shrimp species using Student's t-test. Overall mean WSSV lethal load was $2.86 \times 10^{11}\left(\mathrm{SE} \pm 1.63 \times 10^{11}\right)$ genome copies $\mu \mathrm{g}^{-1}$ of total DNA. In conclusion, WSSV was found to be less virulent in F.duorarum than in L. vannamei by $\mathrm{LD}_{50}$ and mean survival time but not in mean lethal load. This suggests that shrimp resistance is imparted by controlling WSSV loads rather than by tolerating higher loads.
\end{abstract}

Key Words: WSSV-China isolate, median lethal dose $\left(\mathrm{LD}_{50}\right)$, median survival times, lethal loads

Correspondence: R. J. dela Calzada. Address: Department of Fisheries, Visayas State University-Tolosa, Tanghas, Tolosa, Leyte 6503 Philippines. E-mail: reyjdc26@yahoo.com. DOl: $10.32945 /$ atr3416.2012 


\section{INTRODUCTION}

White spot syndrome virus (WSSV) is the causative agent of White Spot Disease (WSD)(OIE 2003). It is an important shrimp pathogen that has been devastating the shrimp farming industry worldwide, causing up to $100 \%$ mortality of farmed shrimps within 3 to 10 days (Lightner, 1996, Chou et al., 1995). WSSV was first recognized in cultured penaeid shrimps in Asia and the Indo-Pacific Region in 1993 (Chou et al., 1995; Wongteerasupaya et al., 1995; Inouye et al., 1994; Inouye et al., 1996). The virus spread rapidly and reached the western hemisphere in 1995 in pond reared Litopenaeus setiferus in a Texas farm (Lightner, 1996).

In L. vannamei, WSSV infection starts with an initial short asymptotic prepatent state. In this state, the virus multiplies and in due time, causes a symptomatic acute infection. Acute infections then may progress and cause death of the shrimp or the shrimp may survive and develop chronic infections (Lotz \& Soto, 2002). WSSV transmission in L. vannamei is more effective through ingestion of infected cadavers than through contact with living infected hosts (Soto \& Lotz, 2001).

Virulence of a pathogen is the strength of the ability to cause disease. It can be measured in a number of ways, e.g., the $\mathrm{LD}_{50}$, the lethal load (quantity of a pathogen that causes death), or the survival curve (median time were $50 \%$ of the population that survives). The $\mathrm{LD}_{50}$ of WSSV for different viral strains and shrimp species has been reported (Prior et al., 2003; EscobedoBonilla et al., 2005; Escobedo-Bonilla et al., 2006). However they have been reported in units of dilution, rather than the number of DNA copies. Viral load is one of the most important factors in the progression and transmission of disease (Durand and Lightner, 2002).

Quantitative PCR has been applied to quantify WSSV lethal loads in shrimps (Durand and Lightner, 2002; Durand et al., 2003; Dhar et al., 2001) and other penaeid virus (Tang and Lightner, 2001; Tang et al., 2004; Dhar et al., 2002). WSSV virulence in $L$. vannamei and $F$. duorarum has also been reported (Chou et al., 1995; Lightner 1996; Lightner et al., 1998; Wang et al., 1999). F. duorarum displayed a degree of resistance to infection and disease, in response to WSSV challenge than L. vannamei (Lightner et al., 1998; Wang et al., 1999). Although F. duorarum was shown to be more resistant than L. vannamei, so far, no study has been conducted to compare their $L_{50} \mathrm{~s}$ and lethal loads and median survival times. In this study, we compared the $\mathrm{LD}_{50}$ of WSSV in the penaeid shrimps Litopenaeus vannamei 
and Farfantepenaeus duorarum using quantitative real time polymerase chain reaction, compared the survival curves of the two shrimp species, and determined the lethal loads of WSSV in the two species of shrimps using q-RTPCR.

\section{MATERIALS AND METHODS}

\section{Experimentalshrimps}

The L. vannamei were SPF Kona stock obtained from the Oceanic Institute in Hawaii. Farfantepenaeus duorarum stock was derived from Specific Pathogen Free (SPF) stock acquired from Texas A\&M Corpus Christi. The shrimp were solely intended for laboratory experiments and stocked in an isolated and biosecure facility. Shrimp selected for the experiments weighed 3-4 $\mathrm{g}$ of the same age.

\section{Viralstock production}

The WSSV viral stock was originally obtained from China, and it has been passed once in L. vannamei stocks. To obtain virus for the study, infection bioassay was conducted in a 500-L circular fiberglass tank containing UV treated 15 ppt artificial salt water at a temperature of 26-27 ${ }^{\circ} \mathrm{C}$. One hundred SPF healthy L. vannamei shrimp (8-10 g) were stocked into the tank and allowed to acclimate for $48 \mathrm{~h}$. The shrimp were fed with commercial shrimp pellets. After acclimation, shrimp were exposed to the WSSV China isolate by intramuscular injection at $0.02 \mathrm{ml}$ of WSSV inoculum $\mathrm{g}^{-1}$ body weight (BW) between the second and third tail segment. Moribund and freshly dead shrimp were collected and frozen at $-80^{\circ} \mathrm{C}$ (Prior et al. 2003). Quantitative real time PCR was done to confirm that these shrimps were infected with WSSV.

In the preparation of the WSSV inocula, gills from infected shrimp were aseptically removed and finely chopped using a sterilized surgical blade. This was suspended in a $0.9 \% \mathrm{NaCl}$ solution at a 1:10 (w/v) dilution of gill tissues to saline solution and was mixed thoroughly using a vortex mixer. The resulting mixture was centrifuged for $20 \mathrm{~min}$ at $3000 \times \mathrm{g}$ at $4^{\circ} \mathrm{C}$. The supernatant was collected and centrifuged again for $13,000 \mathrm{xg}$ at $4^{\circ} \mathrm{C}$ for 20 min (Escobedo-Bonilla et al., 2005). The final supernatant was filtered in a 0.45 um filter and divided into $1.5-\mathrm{ml}$ aliquots, stored at $-80^{\circ} \mathrm{C}$, and served as the viral source for the assays (Prior et al., 2003). 


\section{Bio assaysystem}

The life support system that was used for the bio-assays was the Aquatic Habitat ZF 0601 (Aquatic Habitats ${ }^{\mathrm{TM}}$ ) stand-alone recirculation system with aeration, filtration and UV light. The system utilizes 60 rectangular, 3-L containers. Two systems were used to accommodate the 120 shrimp for each trial with ten shrimp stocked in each container. The systems were filled with 15 ppt seawater by mixing artificial salt (Marine Environment) and filtered fresh tap water. A submersible heater was used to maintain the temperature at $26 \pm 0.5^{\circ} \mathrm{C}$.

Prior to injection, shrimp were placed in a 500-L cylindrical tank and acclimatized to a salinity of 15 ppt for $48 \mathrm{~h}$ inside the bioassay room. Polyester filters inoculated with nitrifying bacteria were placed in the tank for biofiltration. The water was maintained at $26 \pm 0.5^{\circ} \mathrm{C}$.

Shrimp were transferred individually to the aquatic habitat containers. Polyester filters inoculated with nitrifying bacteria were placed in the systems' sump for biofiltration. Ultraviolet light was used to prevent virus contamination among tanks. The shrimp were individually weighed before they were transferred. Temperature and salinity were checked daily and adjusted when necessary.

\section{Experimental infection}

Preliminary injection assay using serial dilutions from 1: 10 through 1 : $1 \times 10^{15}$ was conducted to determine the viral dilutions to be used to estimate the $L D_{50}$ in the final experiment. Specific pathogen free L.vannamei was used in the preliminary WSSV injection assay. Based on the result of the assay, the final viral dilutions for the determination of $L_{50}$ were $1: 1.0 \times 10^{4}, 1: 5.5 \times 10^{4}, 1: 1.0 \times 10^{5}, 1: 5.5 \times 10^{5}$ and $1: 1.0 \times 10^{6}$

Two trials were conducted for L.vannamei to determine WSSV $\operatorname{LD}_{50}$ and one trial for F.duorarum. A total of 20 shrimp were used for each viral dilution in every experiment. A sample of the WSSV inoculum used in every trial was collected and q-PCR was done to determine WSSV genome copies. The result of this was used to determine the total number of virus injected per dilutions for every trial. Saline solution $(0.9 \% \mathrm{NaCl})$ was used to inoculate the negative control shrimp. Shrimp were observed for $7 \mathrm{~d}$ after inoculation. Moribund and dead shrimp were recorded and collected. Hemolymph and pleopods were collected and placed in 1.5-ml test tubes and stored at $-80^{\circ} \mathrm{C}$ until they were analyzed for WSSV by quantitative real 
time PCR (q-PCR). Surviving and negative control shrimp were sacrificed after $7 \mathrm{~d}$ and hemolymph and pleopods were stored at $-80^{\circ} \mathrm{C}$ until they were analyzed for WSSV by PCR as described by Lo et al. (1996).

\section{DNA extraction}

Using the hemolymph of the shrimp, total DNA was extracted using the High Pure PCR template preparation kit following the protocol of the manufacturer (Roche Applied Science, Mannheim Germany). Immediately after extraction, the concentration of total DNA in the sample was estimated using a spectrophotometer.

\section{Quantitative PCRfor WWSV}

The sequences of q-PCR primers and Taq-Man probe specific for WSSV were those of Durand et al. (2003). Total volume for q-PCR reaction per sample was $25 \mu \mathrm{l}$. The reaction mixture consisted of $12.5 \mu \mathrm{l}$ of TaqMan Universal Mix (Applied Biosystems, Foster City USA) that contained Amplitaq Gold DNA polymerase, AmpErase UNG, dNTPs with dUTP and optimized buffer components, $2.5 \mu \mathrm{l}$ of $3 \mu \mathrm{M}$ forward primer (Invitrogen), $2.5 \mu \mathrm{l}$ of $3.0 \mu \mathrm{M}$ reverse primer (Invitrogen), $2.5 \mu \mathrm{l}$ of $1.5 \mu \mathrm{MTaqManProbe}$ (Integrated DNA Technologies) and $5 \mu$ l of sample DNA.

Quantitative polymerase chain reaction amplification was conducted following the procedure of Durand and Lightner (2002) and Durand et al. (2003) using an iCycler Thermal Cycler (BioRad). All samples were tested in triplicate.

The standard for WSSV q-PCR is an oligonucleotide with 5 '-CAA TGG TCC CGT CCT AGA AGC CAT GAA GAA TGC CGT CTA TCA CAC ACT AAT TTC CGG CAA AGC TCG- 3' sequence of 75 bp (Trilink Biotechnologies) corresponding to nucleotides 1008 to 1082 . This standard was stored at $20^{\circ} \mathrm{C}$, serially diluted prior to q-PCR analysis to generate standard curves.

\section{Statistical analysis}

The $\mathrm{LD}_{50}$ was calculated using the Probit Analysis or Logistic Regression of SPSS software, version 16 and the relative median potency was calculated as the ratio of WSSV $\mathrm{LD}_{50} \mathrm{~s}$ for L. vannamei and F.duorarum. Logistic regression was used to compare L. vannamei and F. duorarum 
susceptibility to WSSV. Kaplan-Meir analysis was used to compare survival curves of the shrimp exposed to different WSSV viral doses. Student's $t$-test was performed to to determine the differences in viral loads. Alpha level was set to 0.05 for all statistical tests.

\section{RESULTS}

Quantification of WSSV content in experimental bioassays

Based on q-PCR, the inoculum used in L. vannamei trials 1 and 2 contained $1.58 \times 10^{8} \mathrm{WSSV}$ genome copies $\mu \mathrm{g}^{-1}$ of total DNA or $3.13 \times 10^{6}$ WSSV genome copies $\mu \mathrm{g}^{-1}$ of inoculum and $4.92 \times 10^{8} \mathrm{WSSV}$ genome copies $\mu \mathrm{g}^{-1}$ of total DNA or $5.0 \times 10^{6} \mathrm{WSSV}$ genome copies $\mu \mathrm{g}^{-1}$ of inoculum respectively. The inoculum in the $F$. duorarum trialcontained $8.77 \times 10^{10}$ WSSV genome copies $\mu \mathrm{g}^{-1}$ of total DNA or $1.42 \times 10^{9} \mathrm{WSSV}$ genome copies ${\mu \mathrm{g}^{-1}}^{-1}$ of inoculum. Analysis of variance detected no significant differenceamong the inocula $(\mathrm{P}=0.094)$.

Student's $t$-test did not show significant differences in the concentration of virus in the inocula used for L. vannamei 1 and L. vannamei $2(\mathrm{p}=0.30)$, L. vannamei 1 and F. duorarum $(\mathrm{p}=0.23)$ and L. vannamei 2 and

Table 1. Doses of WSSV intramuscularly injected to Litopenaeus vannamei and Farfantepenaeusduorarum.

\begin{tabular}{lcc}
\hline \multicolumn{2}{c}{ WSSV dose (genome copies $\boldsymbol{\mu g}^{-1}$ total DNA) /shrimp } & WSSV Log Dose \\
\hline L. vannamei trail 1 & & \\
& $2.53 \times 10^{5}$ & 5.40 \\
& $4.60 \times 10^{3}$ & 3.66 \\
$2.53 \times 10^{3}$ & 3.40 \\
& $4.60 \times 10^{2}$ & 2.66 \\
& $2.53 \times 10^{2}$ & 2.40 \\
& & \\
L. vannamei trail 1 & $4.04 \times 10^{5}$ & 5.61 \\
& $1.24 \times 10^{4}$ & 4.09 \\
& $7.35 \times 10^{3}$ & 3.87 \\
& $5.21 \times 10^{3}$ & 3.72 \\
F. duorarum trial & $4.04 \times 10^{3}$ & 3.61 \\
& & \\
& $8.58 \times 10^{6}$ & 6.93 \\
& $1.56 \times 10^{6}$ & 6.19 \\
& $8.58 \times 10^{5}$ & 5.93 \\
& $1.56 \times 10^{5}$ & 5.19 \\
& $8.58 \times 10^{4}$ & 4.93 \\
\hline
\end{tabular}




\section{Median lethal dose}

The $\log \mathrm{LD}_{50}$ estimate for L. Vannamei Trial 1 was 4.16 WSSV genome copies $\mu \mathrm{g}^{-1}$ total DNA (95\% CI: 2.23 to 5.24). The $\log \mathrm{LD}_{50}$ estimate for $L$. vannamei Trial 2 was $4.21 \mathrm{WSSV}$ genome copies $\mu \mathrm{g}^{-1}$ total DNA(95\% CI: 3.22 to 5.02). Combined $\log L_{50}$ value for L. vannamei was $4.20 \mathrm{WSSV}$ genome copies $\mu \mathrm{g}^{-1}$ total DNA(95\% CI: 3.34 to 4.84 ).

The $\log \mathrm{LD}_{50}$ estimate for $F$. duorarum was $5.32 \mathrm{WSSV}$ genome copies $\mu \mathrm{g}^{-1}$ total DNA (95\% CI: 3.78 to 5.96). The relationship of the $\mathrm{LD}_{50}$ s for the two species is shown in the logistic curves (Figures 1 ).

The relative median potency (ratio of $\mathrm{LD}_{50} \mathrm{~s}$ ) of $F$. duorarum to $L$. vannamei was 13.37 . The odds ratio of mortality for $F$. duorarum in reference to $L$. vannamei for the same dose of WSSV virus was 0.121 . This reflects a $12 \%$ reduced risk of WSSV mortality for F. duorarum compared to L. vannamei exposed to the same dose of WSSV.

The log dose estimates represent the effect of increased dose of WSSV to shrimp, regardless of the species. In this experiment, the estimate of this parameter was 1.791. This means that for every log dose increase of WSSV, the effect on the shrimp mortality is almost doubled. Similarly, the odds ratio of log dose indicates the increase in risk of mortality from an increase in WSSV log dose, regardless of the species of shrimp. In this study, the odds ratio is 5.994, which means the risk of mortality for the shrimp, regardless of species, is 6 times greater as the log of dose increases by one log.

\section{Survival Curve}

\section{Litopenaeus vannamei trials}

Shrimp survival and median survival time showed a decreasing trend as WSSV dose increased. In L. vannamei trial 1 , survival for the respective WSSV dose was 20,30,100, 90 and 90\%. While in L. vannamei trial 2 survivals at respective WSSV dose was 5, 25, 50, 90 and 95\%. In L. vannamei trial 1 , mortality due to WSSV infection began $27.83 \mathrm{~h}$ post injection and mortality stopped $51.25 \mathrm{~h}$ post injection while in L. vannamei trial 2, mortality due to WSSV infection began $28.97 \mathrm{~h}$ post injection and ended $69.12 \mathrm{~h}$ post injection. No mortality was observed in the negative control shrimps. Combining doses of trial 1 and 2 resulted in a median survival time and doses for L. vannamei was $51.25 \mathrm{~h}$ at $2.53 \times 10^{2} \mathrm{WSSV}$ genome 


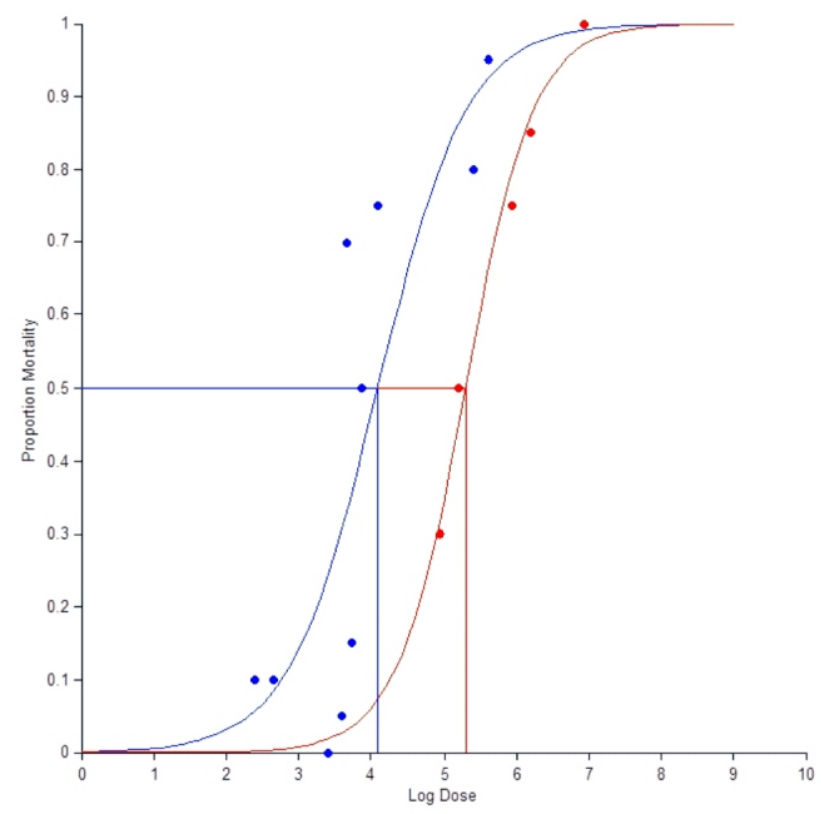

Figure 1. Dose-response curves (Logistic analysis) of L. vannamei (bold circle) andF. duorarum (open circle) with the corresponding WSSV LD $D_{50}$ estimates.

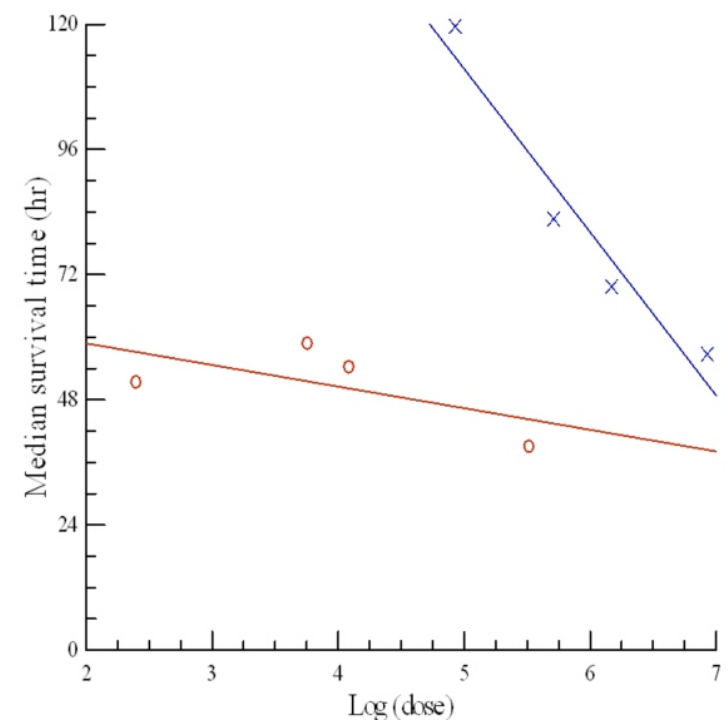

Figure 2. Median survival time of Litopenaeus vannamei (o) and Farfantepenaeus duorarum $(\mathrm{x})$ as a function of WSSV dose. 
copies $\mu \mathrm{g}^{-1}$ total DNA, $58.68 \mathrm{~h}$ at $5.70 \times 10^{3} \mathrm{WSSV}$ genome copies $\mu \mathrm{g}^{-1}$ total DNA, $54.17 \mathrm{~h}$ at $1.24 \times 10^{4} \mathrm{WSSV}$ genome copies $\mu^{-1}$ total DNA, and $38.91 \mathrm{~h}$ at $3.30 \times 10^{5} \mathrm{WSSV}$ genome copies $\mu \mathrm{g}^{-1}$ total DNA. The result showed that medium survival time increases with decreasing WSSV dose

In F. duorarum trial, decreasing trend in shrimp survival and in median survival time as WSSV dose increase was observed. Survival at the respective doses was $0,15,25,50$ and $70 \%$. Mortality due to WSSV infection began $29.63 \mathrm{~h}$ post injection and ended $119.58 \mathrm{~h}$ post injection. No mortality was observed in the negative control shrimps.

Median survival time was longer in F. duorarum than in L. vannamei given the same WSSV dose. To compare the median survival time of the two species of shrimp, we compared the survival curves of shrimp inoculated with doses of $10^{5}$ and $10^{4} \mathrm{WSSV}$ genome copies $\mu \mathrm{g}^{-1}$ total DNA because those doses were common to both species. The means of $10^{5}$ and $10^{4}$ doses were $1.24 \times 10^{4} \mathrm{WSSV}$ genome copies $\mu \mathrm{g}^{-1}$ total DNA and $3.30 \times 10^{5} \mathrm{WSSV}$ genome copies $\mu \mathrm{g}^{-1}$ total DNA for L. vannamei. For F. duorarum were $8.58 \times 10^{4} \mathrm{WSSV}$ genome copies $\mu \mathrm{g}^{-1}$ total DNA and $5.07 \times 10^{5} \mathrm{WSSV}$ genome copies $\mu \mathrm{g}^{-1}$ total DNA. The median survival times for L. vannamei were $54.17 \mathrm{~h}$ at $1.24 \mathrm{x}$ $10^{4} \mathrm{WSSV}$ genome copies $\mu^{-1}$ total DNA and $45.60 \mathrm{~h}$ at $3.30 \times 10^{5} \mathrm{WSSV}$ genome copies $\mu \mathrm{g}^{-1}$ total DNA. For $F$ duorarum, the median survival time was $119.58 \mathrm{~h}$ at $8.54 \times 10^{4} \mathrm{WSSV}$ genome copies $\mu \mathrm{g}^{-1}$ total DNA and $82.67 \mathrm{~h}$ at $5.07 \times 10^{5} \mathrm{WSSV}$ genome copies $\mu^{-1}$ total DNA. Therefore $F$. duorarum showed resistance to WSSV compared with L. vannamei since it took longer for WSSV in F. duorarum to cause $50 \%$ mortality at the same dose.

\section{WSSVlethal loads}

No significant difference existed between lethal loads of the trials. Mean log of WSSV lethal load in L. vannamei trial 1 was 9.72(SE \pm 9.46$)$ with a range from5.02 to 10.92 copies $\mu \mathrm{g}^{-1}$ of total DNA. Meanlog lethal load in $L$. vannamei trial 2 was 7.65 (SE \pm 7.15 ) with a range from4.58 to 8.77 copies $\mu^{-1}$ of total DNA. Combined L. vannamei mean log WSSV lethal load was 9.34(SE \pm 9.09 ) copies $\mu \mathrm{g}^{-1}$ of total DNA with a range from 4.58 to 10.92 copies $\mu \mathrm{g}^{-1}$ of total DNA. For $F$. duorarum the mean log lethal load was 11.80 (SE \pm 11.55 ) with a range from 3.52 to $13.30 \mathrm{WSSV}$ copies $\mu \mathrm{g}^{-1}$ of total DNA. Although close, Student's T-test showed no significant difference in mean lethal load for the two species ( $\mathrm{P}=0.056)$. The overall mean of $\log$ WSSV lethal load in fresh dead and moribund shrimps regardless of species or 
trial was $11.45(\mathrm{SE} \pm 11.21)$ genome copies $\mu \mathrm{g}^{-1}$ of total DNA with a range from 3.52 to 13.30 genome copies $\mu^{-1}$ of total DNA.

\section{DISCUSSION}

Prior to the development of q-PCR for WSSV, the amount of WSSV used in an assay was standardized by dilution, not by viral concentration. Subsequently, q-PCR has been used to determine concentration of WSSV (Durand and Lightner, 2002: Durand et al., 2003). In this study, we evaluated the relative virulence of WSSV-China isolate in the penaeid shrimp, L. vannamei and F. duorarum by employing q-PCR to obtain the WSSV dose in terms of the number of genome copies. This is the first study to estimate the WSSV $\mathrm{LD}_{50}$ in F. duorarum for any isolate and the first to use q-PCR to estimate the $\mathrm{LD}_{50}$ in either F. duorarum or L. vannamei. Although it has been reported that there are differences in virulence of WSSV geographic isolates (Wang et al., 1999), it is not possible to compare our isolate with others because of the lack of knowledge of the precise dose used in studies of other WSSV isolates. The study of Prior et al. (2003) reported $L_{50} \mathrm{~s}$ of $1: 4.44 \times 10^{6}$ and $1: 4.50 \times 10^{6}$ in L. vannamei using WSSV South Carolina isolate. Escobedo-Bonilla et al. (2005) reported median virus infection titers in 60 and $135 \mathrm{~d}$ old juvenile L. vannamei at $10^{6.8}$ and $10^{6.5} \mathrm{SID}_{50} \mathrm{ml}^{-1}$ using WSSV Thailand isolate. Durand et al. (2002) reported that a viral load of $10^{4}$ and $10^{5}$ copies of WSSV China isolate resulted in disease and mortality in L. vannamei when injected intramuscularly. In the same study they found that a WSSV viral load of $10^{5}$ was needed for transmission and mortality in immersion assays. Tan et al. (2001) reported that if the viral load in P. monodon exceeded $10^{6}$ copies then clinical signs of WSSV and mortality were observed.

Although F. duorarum showed greater resistance to WSSV infection than L. vannamei, it is possible that the result would have been different if another method of inoculation was used. Injection trials place virus directly into the shrimp's muscle (Prior et al., 2003) avoiding many host barriers that might prevent pathogen entry (Escobido-Bonilla et al., 2006). Injection assay has been shown to result in more virulent infections that lead to increased mortality in shorter times (Rajendran et al., 1999; Escobido-Bonilla et al., 2005). In the study of Rajendran et al., (1999) cumulative mortality of $100 \%$ was observed within 5-7d in shrimp injected with WSSV and 7-9 d in shrimp fed infected tissue. Escobedo-Bonilla et al., 
(2005) reported that virus titers were reduced ten-fold in oral intubation compared to intramuscular inoculation. Likewise, Durand et al. (2002) reported that a minimum of $10^{5} \mathrm{WSSV}$ copies is necessary to transmit disease in shrimp by immersion but only $10^{4}$ WSSV copies by injection resulted in an acute infection and disease. In this study, a dose of a little as $10^{2} \mathrm{WSSV}$ genome copies per $\mu \mathrm{g}^{-1}$ of total DNA was found to transmit WSSV virus and cause infection and mortality in L. vannamei. Possibly the same amount of virus is enough to transmit WSSV virus and cause infection in $F$. duorarum, but the length of time to mortality might be longer and cumulative mortality will be lower.

Analysis of the median survival time of shrimps injected with $10^{5}$ and $10^{4}$ WSSV genome copies showed that $F$ duorarum has longer median survival times compared with those for L. vannameiafter $7 \mathrm{~d}$. The median survival time at $10^{5}$ and $10^{4} \mathrm{WSSV}$ copies $\mu \mathrm{g}^{-1}$ of total DNA (45.60 -54.17 h) for $L$. vannamei is within the range reported by Durand et al. (2002) of 49$52 \mathrm{~h}$, which is a highly acute infection compared to F. duorarum which almost doubled the median survival time (82.67-119.58 h) when injected with the same amount of WSSV dose. In addition, at a dose of $10^{5}$ WSSV genome copies, mortality was higher in L. vannamei at 80-95\% compared to F. duorarum, with $50-75 \%$ mortality. These findings confirm the study of Lightner et al. (1998) in which F. duorarum displayed resistance to WSSV. Lightner et al. (1998) experimentally infected L. vannamei, L. setiferus, $F$. duorarum and F. aztecus with a WSSV isolate from China by feeding and found that WSSV challenge of postlarval shrimp resulted in severe infections in L. vannamei and L. setiferus and 100\% cumulative mortality and $27 \%$ cumulative mortality in F. aztecus and no signs of clinical infection and $0 \%$ cumulative mortality in F. duorarum. Likewise, Wang et al. (1999) using oral inoculation of six WSSV geographic isolates reported that all the geographic isolates were more virulent to L. vannamei than to F. duorarum. Litopenaeus vannamei challenged in this study died $14 \mathrm{~d}$ after feeding while F. duorarum juveniles showed resistance to WSSV with $40 \%$ to $65 \%$ shrimp surviving after $18 \mathrm{~d}$ challenge. The findings of this study however differed from that of Soto et al. (2002) who reported no statistical difference detected in final mean mortality rates between L. vannamei and $F$. duorarum.

The taxonomic differences between L. vannamei than to F. duorarum might explain the difference in virulence. Litopenaeus vannamei belongs to genus Litopenaeus and F. duorarum belongs to the genus Farfantepenaeus 
(Lightner et al., 1998). Shrimp of genus Farfantepenaeus have been reported to be less susceptible when challenged with other penaeid viruses. Overstreet et al. (1997) demonstrated that L. setiferus and $L$. vannamei but not $F$. duorarum or $F$. aztecus could be killed by Taura syndrome virus (TSV). Erickson et al. (1996) reported that juvenile specimens of L. setiferus, L. aztecus and F. duorarum were not killed when fed $15 \%$ body weight TSV infected $L$. vannamei but over $90 \%$ of $L$. vannamei were. This shows that $L$. vannamei is the most susceptible species of the subgenus Litopenaeus. Studies of experimental WSSV infections in $P$. monodon, M. japonicus, F. penicillatus, F. chinensis, P. semisulcatus, F indicus, M. monoceros and $M$. dobsonii have shown no greater resistance for these species than for L. vannamei with $100 \%$ mortality as soon as $2 \mathrm{~d}$ after exposure (Chou et al. 1995; Tan et al., 2001; Rajendran et al., 1999; Zhan et al., 1998; Hasson et al. 2006). Farfantepenaeus duorarum may be the most resistant penaeid shrimp identified to date. This doesn't mean however that they will not develop white spot syndrome disease when infected with the virus.

The study found no significant difference in the lethal load of WSSV in the two shrimp species as determined by q-PCR. That is to say that although F. duorarum is more resistant to WSSV than L. vannamei, the resistance is not imparted by tolerating a greater load of virus by F. duorarum. However, the variability in WSSV lethal load among shrimp of the same species suggests that other factors are involved. For example, the state of shrimp health at the time of an experiment, the immune response of a shrimp, and the dose of virus injected (Durand and Lightner, 2002), cannibalism, shrimp density and rearing conditions (Wu et al., 2001).The mean WSSV lethal load in the two species of shrimp in this study was $2.86 \times 10^{11}$ genome copies $\mu \mathrm{g}^{-1}$ of total DNA. Using WSSV- China isolate, Durand et al. (2002) found that the WSSV lethal load in moribund penaeid shrimps P. monodon, L. stylirostris and L. vannamei had the mean WSSV lethal load of $3.0 \times 10^{10}$ WSSV genome copies $\mu \mathrm{g}^{-1}$ of total DNA, while for naturally infected $P$. monodon, the WSSV mean lethal copy number was $2.10 \times 10^{6}$ genome copies $\mu \mathrm{g}^{-1}$ of total DNA and for L. vannamei the WSSV mean lethal load was $1.60 \times 10^{9}$ genome copies $\mu \mathrm{g}^{-1}$ of total DNA. This implies that using WSSVChina isolate, WSSV mean lethal load could reach very high numbers of WSSV, regardless of whether they are naturally or experimentally infected and or shrimp species. Quantification of lethal viral loads have also been done in other penaeid viruses like infectious hypodermal and 
hematopoietic necrosis virus (IHHNV) and Taura syndrome virus (TSV) using quantitative real time PCR tools. Tang and Lightner (2001) reported the viral loads IHHNV in naturally infected L. stylirostris juveniles from the Gulf of Mexico, hatchery raised small juveniles L. stylirostris from Guam and in farm raised post larvae $P$. monodon from the Philippines. They reported maximum level of IHHNV in these shrimps in the order of $10^{9}$ copies $\mu \mathrm{g}^{-1}$ of total DNA with observed high level of mortalities. Tang et al. (2004) used qPCR in the quantification of TSV in infected juvenile L. vannamei. Results showed that acute and chronically infected shrimp contained $10^{6}-10^{8}$ copies of TSV per microgram of RNA in both gills and pleopods with cumulative mortality in acute infected shrimp of $71 \%$.

\section{CONCLUSION}

In conclusion, the present study demonstrates that WSSV virus is more virulent to $L$. vannamei than to $F$. duorarum as measured by $\mathrm{LD}_{50}$ and survival curves. However, the resistance is not provided by the greater ability of $F$. duorarum to tolerate a greater viral loads present. This observation may indicate that other factors, such as, but not limited to stocking density, stocking condition (individually and collectively reared shrimp), mode of transmission (Wu et al., 2001) and size of host (Wu et al., 2001; Lotz, 1997) in the rearing systems plays a role in the virulence.

\section{ACKNOWLEDGMENT}

Partial funding for this research was provided by a grant from the United States Department of Agriculture, CSREES grant number 200238808-01381. Rey J. dela Calzada is supported by the Fulbright-Philippine Agriculture Scholarship Program. The authors would like to thank the anonymous reviewers for comments regarding the manuscript.

\section{REFERENCES}

CHOU H., C. HUANG, C. WANG , H. CHIANG and C. LO. 1995. Pathogenicity of a baculovirus infection causing white spot syndrome in cultured penaeid shrimp in Taiwan. Diseases of Aquatic Organisms 23: 165-173. 
DHAR A.K., M.M. ROUX and K.R. KLIMPEL. 2001. Detection and Quantification of Infectious Hypodermal and Hematopoietic Necrosis Virus and White Spot Virus in Shrimp Using Real-Time Quantitative PCR and SYBR Green Chemistry. Journal ofClinical Microbiology 39(8): 2835-2845.

DHAR A.K., M.M. ROUX and K.R. KLIMPEL. 2002. Quantitative assay for measuring the Taura syndrome virus and yellow head virus load in shrimp by real-time RT-PCR using SYBR Green chemistry. Journal of Virological Methods 104(1): 69-82.

DIAGNOSTIC MANUAL FOR AQUATIC ANIMAL DISEASES. 2003. OIE (World Organisation for Animal Health), Paris, France.

DURAND S, D.V. LIGHTNER, L.M. NUNAN, R.M. REDMAN, J. MARI and J.R. BONAMI.1996. Application of gene probes as diagnostic tools for White Spot Baculovirus (WSBV) of penaeid shrimp. Diseases of Aquatic Organisms 27:59-66.

DURAND S., D.V. LIGHTNER, R.M. REDMAN and J.R. BONAMI. 1997. Ultrastructure and morphogenesis of white spot syndrome baculovirus (WSSV). Diseases of Aquatic Organisms 29: 205-211.

DURAND S.V. and D.V. LIGHTNER. 2002. Quantitative Real Time PCR for the measurement of white spot syndrome virus in shrimp. Journal of Fish Diseases 25:381-389.

DURAND S.V., R.M. REDMAN, L.L. MOHNEY, K. TANG-NELSON, J.R. BONAMI and D.V. LIGHTNER. 2003. Qualitative and quantitative studies on the relative virus load of tails and heads of shrimp acutely infected with WSSV.Aquaculture 216: 9-18.

ERICKSON H.S., A.L. LAWRENCE, K.L. GREGG, P.F. FRELIER, J.M. LOTZ, C. SEYMORE and D.A. MCKE. 1996. Sensitivity of Penaeus vannamei, Penaeus setiferus, Penaeus aztecus and P. duorarum to Taura Syndrome Virus Infected Tissue. Aquaculture America 1996 Book of Abstracts, Arlington, Texas. pp. 37-38. 
ESCOBEDO-BONILLA C.M., M. WILLE, V. ALDAY-SANZ, P. SORGELOOS, M.B. PENSAERT and H.J. NAUWYNCK. 2005. In vivo titration of white spot syndrome virus (WSSV) in specific pathogen-free Litopenaeus vannamei by intramuscular and oral routes. Diseases of Aquatic Organisms 66: 163-170.

HASSON K.W., Y. FAN, T. REISINGER, J. VENUTI and P.W. VARNER. 2006. White-spot syndrome virus introduction into the Gulf of Mexico and Texas freshwater systems through imported, frozen bait-shrimp. Diseases of Aquatic Organisms 71: 91-100.

INOUYE K., S. MIWA , N. OSEKO, H. NAKANO, T. KIMURA, K. MOMOYAMA, and M. HIRAOKA. 1994. Mass Mortalities of Cultured Kuruma Shrimp Penaeus japonicus in Japan in 1993: Electron Microscopic Evidences of the Causative Virus. Fish Pathology 29(2): 149-158.

INOUYE K., K. YAMANO, N. IKEDA, T. KIMURA, H. NAKANO, K. MOMOYAMA, J. KOBAYASHI and S. MIYAJIMA. 1996. The Penaied Rod-Shaped DNA Virus (PRDV), which Causes Penaeid Acute Viremia (PAV). Fish Pathology 31(1): 39-45.

LIGHTNER D.V. 1996. A handbook of pathology and diagnostic procedures for diseases of penaeid shrimp. Department of Veterinary Science, University of Arizona, Tucson, AZ.

LIGHTNER D.V., K.W. HASSON, B.L. WHITE and R.M. REDMAN. 1998. Experimental Infection of Western Hemisphere Penaeid Shrimp with Asian White Spot Syndrome Virus and Asian Yellow Head Virus. Journal of Aquatic Animal Health 10:271-281.

LO C., C. HO, S. PENG, C. CHEN, H. HSU, Y. CHIU, C. CHANG, K. LIU, M. SU, C. WANG and G. KOU. 1996. White spot syndrome baculovirus (WSBV) detected in cultured and captured shrimp, crabs and other arthropods. Diseases of Aquatic Organisms 27: 215-225.

LOTZ J.M. 1997. Effect of host size on the virulence of Taura Syndrome Virus to the marine shrimp Penaeus vannamei (Crustacea: Penaeidae). Diseases of Aquatic Organisms 30: 45-51. 
LOTZ J.M. and M.A. SOTO. 2002. Model of white spot syndrome virus (WSSV) epidemics in Litopenaeus vannamei. Diseases of Aquatic Organisms 50: 199-209.

Nimaviridae.http://www.ncbi.nlm.nih.gov/ICTVdb/ICTVdB/index.htm.

OVERSTREET R.M., D.V. LIGHTNER, K.W. HASSON, S. MCILWAIN and J.M. LOTZ. 1997. Susceptibility to Taura Syndrome Virus of some Penaied Shrimp Species Native to the Gulf of Mexico and Southeastern United States.Journal of Invertebrate Pathology 69: 165-176.

PRIOR S., C.L. BROWDY, E.F. SHEPARD, R. LARAMORE and P.G. PARNELL. 2003. Controlled bioassay systems for determination of lethal infective doses of tissue homogenates containing Taura syndrome or white spot syndrome virus. Diseases of Aquatic Organisms 54: 89-96.

RAJENDRAN K.V., K.V. VIJAYAN, T.C. SANTIAGO and R.M. KROL. 1999. Experimental host range and histopathology of white spot syndrome virus (WSSV) infection in shrimp, prawns, crabs and lobsters from India. Journal of Fish Disease 22: 183-191.

RODRIGUES J., B. BAYOT, Y. AMANO, F. PANCHANA, I. DE BLAS, V. ALDAY and J. CALDERON. 2003. White spot syndrome virus infection in cultured Penaeus vannamei (Boone) in Ecuador with emphasis on histopathology and ultrastructure. Journal of Fish Disease 26: 439-450.

SOTO M.A. and J.M. LOTZ. 2001. Epidemiological parameters of white spot syndrome virus (WSSV) infections in Litopenaeus vannamei and Litopenaeus setiferus. Journal of Invertebrate Pathology 78: 9-15.

SOTO M.A., V.R. SHERVETTE and J.M. LOTZ. 2002. Susceptibility of Litopenaeus vannamei and Farfantepenaeus duorarum to white spot syndrome virus (WSSV) and infection of Menippe adina with WSSV. Proceedings of the Gulfand Caribbean Fisheries Institute 53:38 - 45.

SPSS (2002) SPSS Version 11.5. SPSS, Chicago, IL. 
SYSTAT (2002) Systat Version 12.0.Systat Software, Point Richmond, CA.

TAN L.T., J.M. SOON, K.L. LEE, M. SHARIFF, M.D. HASSAN and A.R. OMAR. 2001. Quantitative analysis of an experimental white spot syndrome virus(WSSV) infection in Penaeus monodon Fabricius using competitive polymerase chain reaction. Journal of Fish Diseases 24: 315-232.

TANG K.F.J. and D.V. LIGHTNER. 2001. Detection and quantification of infectious hypodermal and hematopoietic necrosis virus in penaeid shrimp by real-time PCR. Diseases of Aquatic Organisms 44: 79-85.

TANG K.F.J., J. WANG and D.V. LIGHTNER. 2004. Quantification of Taura syndrome virus by RT-PCR with a TaqMan assay. Journal of Virological Methods 115: 109-114.

VAN HULTEN M.C.W., J. WITTEVELDT, S. PETER, N. KLOOSTERBOER, R. TARCHINI, M. FIERS, H. SANDBRINK, K.R. LANKHORST and J.M. VLAK 2001. The white spot syndrome virus DNA genome sequence. Virology 286: 7-22.

WANG C., C. LO, J. LEU, C. CHOU, C. YEH, H. CHOU, M. TUNG, C. CHANG, M. SU and G. KOU. 1995. Purification and genomic analysis of baculovirus associated with white spot syndrome (WSBV) of Penaeus monodon. Diseases of Aquatic Organisms 23: 239-242.

WANG Q., B.L. WHITE, R.M. REDMAN, and D.V. LIGHTNER. 1999. Peros challenge of Litopenaeus vannamei postlarvae and Farfantepenaeus duorarum juveniles with six geographic isolates of white spot syndrome virus. Aquaculture 170: 179-194.

WONGTEERASUPAYA C., J.E. VICKERS, S. SRIURAIRATANA, G.L. NASH, A. AKARAJAMORN, V. BOONSAENG, S. PANYIM, A. TASSANAKAJON, B. WITHYACHUMNARNKUL and T.W. FLEGEL. 1995. A non-occluded, systematic baculovirus that occurs in cells of ectodermal and mesodermal origin and causes mortality in the black tiger prawn Penaeusmonodon. Diseases of Aquatic Organisms 21: 69-77 
WU J.L., A. NAMIKOSHI, T. NISHIZAWA, K. MUSHIAKE, K. TERUYA and K. MUROGA. 2001. Effects of shrimp density on transmission of penaeid acute viremia in Penaus japonicus by cannibalism and waterborne route. Diseases of Aquatic Organisms 47:129-135.

YANG F., J. HE, X.H. LIN, Q. LI, D. PAN, X. ZHANG and X. XU. 2001. Complete genome sequence of the shrimp white spot bacilliform virus. Journal of Virology 75: 11811-11820.

ZHAN W.B., Y.H. WANG, J.L. FRYER, K.K. YU, H. FUKUDA and Q.X. MENG. 1998. White spots yndrome virus infection of cultured shrimp in China. Journal of Aquatic Animal Health 10: 405-410. 